\title{
WIEDZA STUDENTÓW STUDIÓW STACJONARNYCH I NIESTACJONARNYCH PIELĘGNIARSTWA NA TEMAT POBIERANIA KRWI DO BADAŃ BAKTERIOLOGICZNYCH
}

\section{KNOWLEDGE OF FULL- AND PART-TIME STUDENTS OF NURSING FACULTY ON BLOOD SAMPLING FOR BACTERIOLOGICAL EXAMINATION}

\author{
Oktawia Kościńska, Beata Sokół-Leszczyńska², Piotr Leszczyński², Grażyna Młynarczyk² \\ ${ }^{1}$ absolwentka WNOZ kierunek pielęgniarstwo, studia II stopnia \\ Warszawski Uniwersytet Medyczny \\ ${ }^{2}$ Katedra i Zakład Mikrobiologii Lekarskiej \\ Warszawski Uniwersytet Medyczny
}

DOI: https://doi.org/10.20883/pielpol.2017.59

\section{STRESZCZENIE}

Cel. Ocena, jaką wiedzę na temat patomechanizmu i objawów zakażenia łożyska naczyniowego oraz przygotowania do pobierania i przesyłania próbek krwi do badań bakteriologicznych mają studenci Wydziału Nauki o Zdrowiu kierunku pielęgniarstwo.

Materiał i metody. W badaniu uczestniczyło łącznie 120 studentów kierunku pielęgniarstwo: 2. i 3. roku studiów stacjonarnych I stopnia, 1. i 2. roku studiów stacjonarnych || stopnia oraz studentów studiów I stopnia niestacjonarnych (tzw. pomostowych). Kwestionariusz został opracowany specjalnie na potrzeby tego badania. Studenci w ramach przedmiotów: mikrobiologia (studia I stopnia) i pielęgniarstwo epidemiologiczne (studia || stopnia) mieli w programie nauczanie teoretyczne pobierania krwi do badań bakteriologicznych.

Wyniki. Z punktu widzenia mikrobiologa wyniki ankiety wykazały, że wiedza badanych studentów była w znacznym stopniu niewystarczająca, co bezpośrednio może być przyczyną istotnych błędów przedanalitycznych wpływających negatywnie na wynik badania.

Wnioski. Uzyskane wyniki wskazują na potrzebę zmiany sposobu nauczania studentów oraz potwierdzają konieczność systematycznego szkolenia personelu pielęgniarskiego przez personel laboratorium mikrobiologicznego.

SŁOWA KLUCZOWE: pobieranie próbek krwi, czas i warunki transportu, kształcenie.

\section{Wprowadzenie}

Zakażenia krwi wśród zakażeń szpitalnych charakteryzują się największą śmiertelnością. Ze względu na możliwość niewłaściwego wyboru antybiotyku do terapii empirycznej w procesie diagnostyczno-leczniczym konieczne jest jak najszybsze rozpoczęcie celowanego leczenia, w oparciu o wynik badania mikrobiologicznego. W diagnostyce zakażeń bierze udział wielu człon-

\begin{abstract}
Aim. To assess the knowledge of pathomechanisms and symptoms of vascular infection and preparation of students of the Faculty of Health Sciences and Nursing for the collection and transfer of blood samples to the bacteriological lab.

Material and methods. The study included a total of 120 students: 2nd and 3rd year of full-time studies for the bachelor's degree, 1st and 2nd year of of full-time studies for the master's degree and part-time studies for the bachelor's degree. The questionnaire was prepared for the purpose of this study. Students of the microbiology course (bachelor's degree) and epidemiological nursing (master's degree) covered blood sampling for the bacteriological examination.

Results. The results indicate the need to change the way of teaching and confirms the need for systematic training of nursing staff by microbiological laboratory staff.

Conclusion. From the viewpoint of the microbiologist, survey results showed that the students' knowledge is not sufficient and can directly lead to serious pre-analytical errors in the diagnosis of vascular infections.
\end{abstract}

KEYWORDS: blood specimen collection, transport and storage conditions, education.

ków zespołu terapeutycznego, jednak praca wykonana przez pielęgniarkę ma tu kluczowe znaczenie: zwykle jako pierwsza reaguje na patologiczne objawy - dreszcze, podwyższoną temperaturę - najczęściej do jej zadań należy także pobranie krwi do badania mikrobiologicznego, zgodnie ze zleceniem lekarza.

Wg Ustawy z dnia 15 lipca 2011 r. o zawodach pielęgniarki i położnej [1] „wykonywanie zawodu pielęgniar- 
ki polega na udzielaniu (...) świadczeń zdrowotnych, a w szczególności (...) diagnostycznych (...)" - samodzielnie w określonym zakresie świadczeń oraz realizując zlecenia lekarskie w procesie diagnostyki. Ponadto, zgodnie z Rozporządzeniem Ministra Zdrowia z dnia 7 listopada 2007 r. w sprawie rodzaju i zakresu świadczeń zapobiegawczych, diagnostycznych, leczniczych i rehabilitacyjnych udzielanych przez pielęgniarkę lub położną samodzielnie bez zlecenia lekarskiego [2], pielęgniarka specjalistka w dziedzinie pielęgniarstwa jest uprawniona do kierowania na badania lub pobierania materiałów (takich jak: mocz, kał, plwocina, wymaz z nosa, gardła i narządów płciowych i inne wydzieliny) do badań bakteriologicznych. Wobec powyższego niezmiernie istotna jest zarówno znajomość podstaw teoretycznych, jak i umiejętność prawidłowego pobierania próbek materiału, zwłaszcza krwi.

W Rozporządzeniu Ministra Zdrowia z dnia 23 marca 2006 r. w sprawie standardów jakości dla medycznych laboratoriów diagnostycznych i mikrobiologicznych [3] zobligowano kierownika laboratorium mikrobiologicznego do opracowania, wdrożenia i stosowania procedur m.in. w zakresie pobierania i transportu materiału do badań oraz udostępniania ich zleceniodawcom. Zleceniodawcy z kolei potwierdzają zapoznanie się z tymi procedurami i mają obowiązek pobierania materiału do badań laboratoryjnych zgodnie z tymi procedurami. Powinny one uwzględniać sposób przygotowania pacjenta, rodzaj i objętość pobieranego materiału, sposób pobrania materiału do badania, a także transport: dopuszczalny czas, sposób i zakres temperatur.

\section{Cel}

Celem pracy była ocena przygotowania studentów (późniejszych absolwentów) Wydziału Nauki o Zdrowiu kierunku pielęgniarstwo studiów stacjonarnych i niestacjonarnych do pobierania i przesyłania próbek krwi do badań bakteriologicznych oraz ocena ich wiedzy teoretycznej na temat źródeł, przyczyn i objawów zakażenia łożyska naczyniowego.

\section{Materiał i metody}

W badaniu został użyty kwestionariusz przygotowany specjalnie na potrzeby tej pracy. W badaniu wzięło udział łącznie 120 studentów (117 kobiet i 3 mężczyzn). Ankiete przeprowadzono w okresie od kwietnia do czerwca 2013 roku wśród studentów studiów stacjonarnych I stopnia (2. (20 osób) i 3. rok (20 osób)), II stopnia (1. (20 osób) i 2. rok (20 osób)) oraz studentów studiów niestacjonarnych I stopnia (tzw. pomostowych, 40 osób) na kierunku pielęgniarstwo Wydziału Nauki o Zdrowiu Warszawskiego Uniwersytetu Medycznego. Wśród ankietowanych 25 osób miało mniej niż 25 lat,
13 osób było w wieku 25-35 lat, 21 osób - 35-45 lat i 24 osoby miały powyżej 45 lat. Ponadto $23 \%$ ankietowanych pracowało w zawodzie ponad 21 lat, 12\% - 11-20 lat, 2\% -6-10 lat, 16\% - mniej niż 5 lat, 47\% osób jeszcze nie podjęło pracy w zawodzie (studenci studiów II stopnia). Ankietowani otrzymali kwestionariusz bezpośrednio od osoby przeprowadzającej badanie oraz zostali poinformowani o anonimowości i dobrowolności udziału w badaniach.

\section{Metody statystyczne}

Ocenę i analizę porównawczą uzyskanych wyników przeprowadzono za pomocą statystyki opisowej. Do analizy statystycznej wykorzystano pakiet statystyczny Statistica (wersja $10 \mathrm{PL}$ ). Do porównania wyników punktowych między grupami zastosowano nieparametryczny test U Manna-Whitneya, natomiast do analizy zależności między danymi liczbowymi użyto współczynnika korelacji rangowej par Spearmana. Za próg istotności statystycznej przyjęto $p<0,05$.

\section{Wyniki}

Wśród 120 respondentów 97,5\% to kobiety a 2,5\% mężczyźni. Aktywność zawodową deklarowało 47,5\% badanych studentów. Podczas wykonywania obowiązków służbowych $26 \%$ ankietowanych nigdy nie pobierało próbek krwi na posiew, a 50\% wykonywało tę czynność rzadziej niż raz w miesiącu. Zaledwie 16\% studentów czynnych zawodowo pobierało krew do badań mikrobiologicznych 1-2 razy w miesiącu, a tylko 10\% - od kilku do kilkunastu razy w miesiącu. Spośród badanych studentów 55\% nigdy nie pobierało ani nie ćwiczyło na fantomie pobierania krwi na posiew podczas zajęć na studiach, 30\% studentów wykonywało tę czynność tylko raz w czasie studiów, a zaledwie 25\% ankietowanych - kilkukrotnie.

Spośród badanych studentów 62\% uważało, że obowiązek przygotowania skierowania do laboratorium mikrobiologicznego spoczywa na lekarzu i nie dotyczy bezpośrednio personelu pielęgniarskiego. Aż 87\% nie wiedziało, jakie dane należy podać na skierowaniu, a tylko 13\% ankietowanych rozumiało celowość umieszczania na skierowaniu informacji o miejscu przesłania wyniku (klinika/oddział/piętro) lub istotnych danych dotyczących pacjenta (np. nazwa przyjmowanego antybiotyku lub rozpoznanie). Spośród badanych 37,5\% respondentów uważało, że to lekarz wpisuje wszystkie niezbędne informacje na karcie zleceń, a 30\% badanych po otrzymaniu od lekarza informacji o wstępnym rozpoznaniu zasięgałoby opinii pracowni mikrobiologicznej o właściwym sposobie pobrania i transportu próbek krwi. Spośród ankietowanych $27,5 \%$ wiedziało, ile próbek i w jakim czasie należy pobrać w zależności od 
wstępnego rozpoznania lekarskiego, a 5\% uważało, że lekarz słownie zleca schemat pobrania krwi - bez konieczności wpisania do karty zleceń. Tylko 0,83\% ankietowanych prawidłowo potrafiło samodzielnie przedstawić schematy pobierania krwi. Spośród ankietowanych 48,3\% miało świadomość, iż krew na posiew powinna być pobierana pół godziny przed szczytem gorączki, a 37,5\% studentów było przekonanych, iż czynność ta powinna być wykonana na szczycie gorączki. Wśród badanych studentów $87 \%$ nie rozumiało konieczności pobierania więcej niż jednej próbki krwi.

Dla $87 \%$ respondentów najbardziej znanym objawem mogącym świadczyć o zakażeniu łożyska naczyniowego była gorączka lub hipotermia. Tylko 11\% studentów wiedziało, że występowanie dreszczy, tachykardii, tachypnoe lub bezdechu, obniżonego lub podwyższonego ciśnienia krwi, zaburzeń świadomości, bladości powłok skórnych, oligurii/anurii przemawia za zakażeniem. Ponadto $66 \%$ ankietowanych uważało, że obecność centralnego cewnika naczyniowego sprzyja bakteriemii, a tylko $8 \%$ wiedziało, że obecność bakterii w łożysku naczyniowym może występować w: septycznym zapaleniu stawów, zapaleniu płuc, zapaleniu wsierdzia, zapaleniu otrzewnej, zapaleniu opon mózgowo-rdzeniowych, zakażeniu układu moczowego, durze brzusznym i rzekomym, przetaczaniu krwi, żywieniu pozajelitowym, przetaczaniu płynów infuzyjnych, zakażeniach skóry, zakażeniach związanych z obecnością ciała obcego (endoproteza), chorobach zębów i przyzębia, jako powikłanie po zabiegach operacyjnych, u pacjentów z ropniami o różnej lokalizacji, a także po inwazyjnych zabiegach w obrębie jamy ustnej (np. ekstrakcja zęba) czy nawet po czyszczeniu zębów.

Do pobrania krwi na posiew 63\% studentów użyłoby niejałowych rękawiczek, natomiast 37\% wybrałoby rękawiczki jałowe; 35,8\% ankietowanych nie widziało potrzeby dezynfekcji rąk w tej procedurze.

Spośród ankietowanych 38\% zdezynfekowałoby skórę pacjenta wg obowiązujących w placówce medycznej zaleceń. Świadomość, iż efekt dezynfekcyjny preparatów do stosowania na skórę zachodzi dopiero po upływie czasu wskazanego przez producenta miało $60 \%$ badanych, a $67 \%$, że źródłem zanieczyszczenia próbki krwi może być skóra pacjenta, ręce osoby pobierającej oraz/lub skontaminowany sprzęt. Wśród badanych $60 \%$ studentów zdezynfekowałoby gumowy korek przed wprowadzeniem krwi do butelek z podłożem namnażająco-transportowym. Igłę po pobraniu krwi od pacjenta, przed wprowadzeniem krwi do podłoża zmieniłoby $87 \%$ badanych. Również $87 \%$ ankietowanych potrafiło wymienić błędy przedanalityczne, ale $60 \%$ nie potrafiło określić ich wpływu na wynik badania mikrobiologicznego. Aż 92\% ankietowanych miało świadomość, iż pobrany materiał powinno się dostarczyć do laboratorium w możliwie najkrótszym czasie.

Wśród ankietowanych studentów stacjonarnych studiów I stopnia 65\% stwierdziło, że najwięcej informacji na temat pobierania i przesyłania krwi do badań mikrobiologicznych uzyskało na zajęciach z mikrobiologii. Wśród studentów studiów II stopnia 35\% ankietowanych uważało, że najwięcej informacji uzyskali na zajęciach z mikrobiologii na studiach I stopnia, 30\% - na zajęciach z epidemiologii/pielęgniarstwa epidemiologicznego prowadzonych w Katedrze i Zakładzie Mikrobiologii Lekarskiej, a 27,5\% - w miejscu pracy.

Wśród studentów większość deklarowała, iż wiedzę z zakresu pobierania krwi na posiew pogłębia i aktualizuje głównie podczas wewnętrznych szkoleń w miejscu pracy (40\%) i w czasie zajęć na uczelni (38\%), natomiast $25 \%$ nie było zainteresowanych doszkalaniem się.

Na podstawie uzyskanych wyników ankiety stwierdzono zależność pomiędzy poziomem wiedzy studentów a stażem pracy i wiekiem. Analiza wykazała odwrotną korelację między uzyskanym wynikiem ankiety (odsetek poprawnych odpowiedzi) a wiekiem studentów pielęgniarstwa $(r=-0,34, p<0,05)$ oraz stażem pracy $(r=-0,26, p<0,05)$ (Ryciny 1 i 2). 


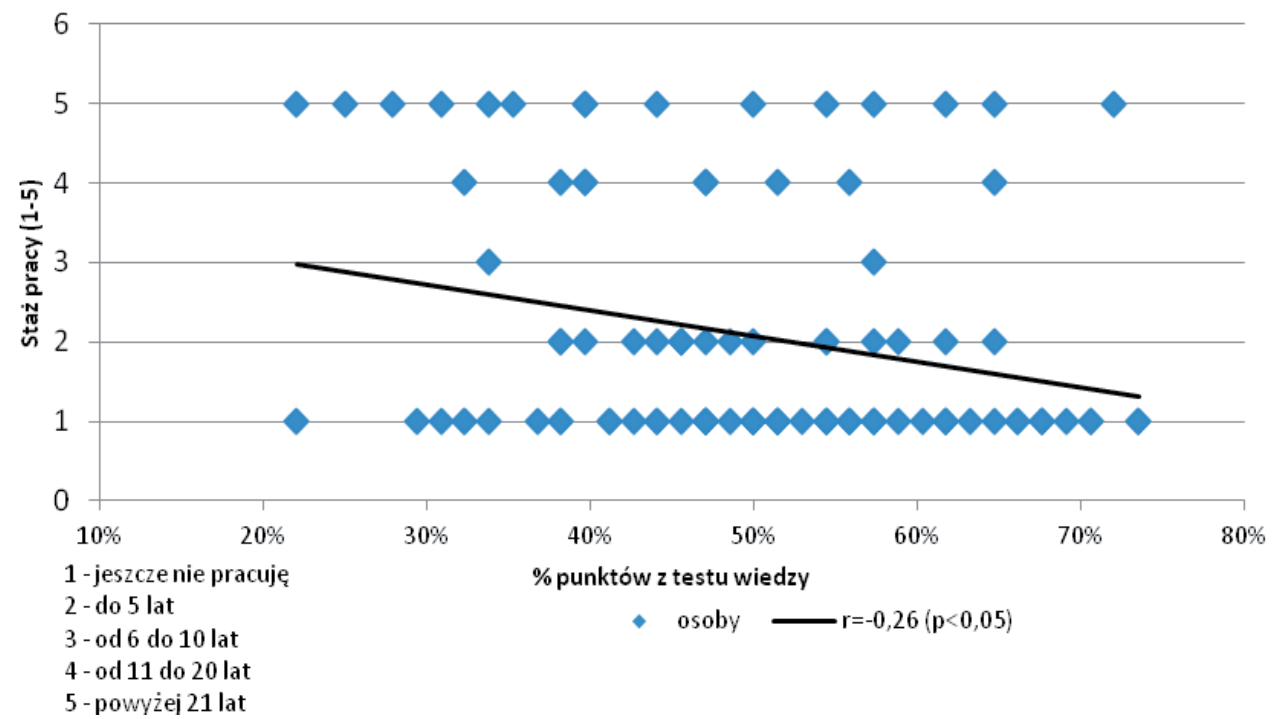

Rycina 1. Zależność prawidłowych odpowiedzi od stażu pracy ankietowanych Figure 1. The relationship between correct answers and the length of respondents' seniority

Źródło: badania własne

Source: author's own materials

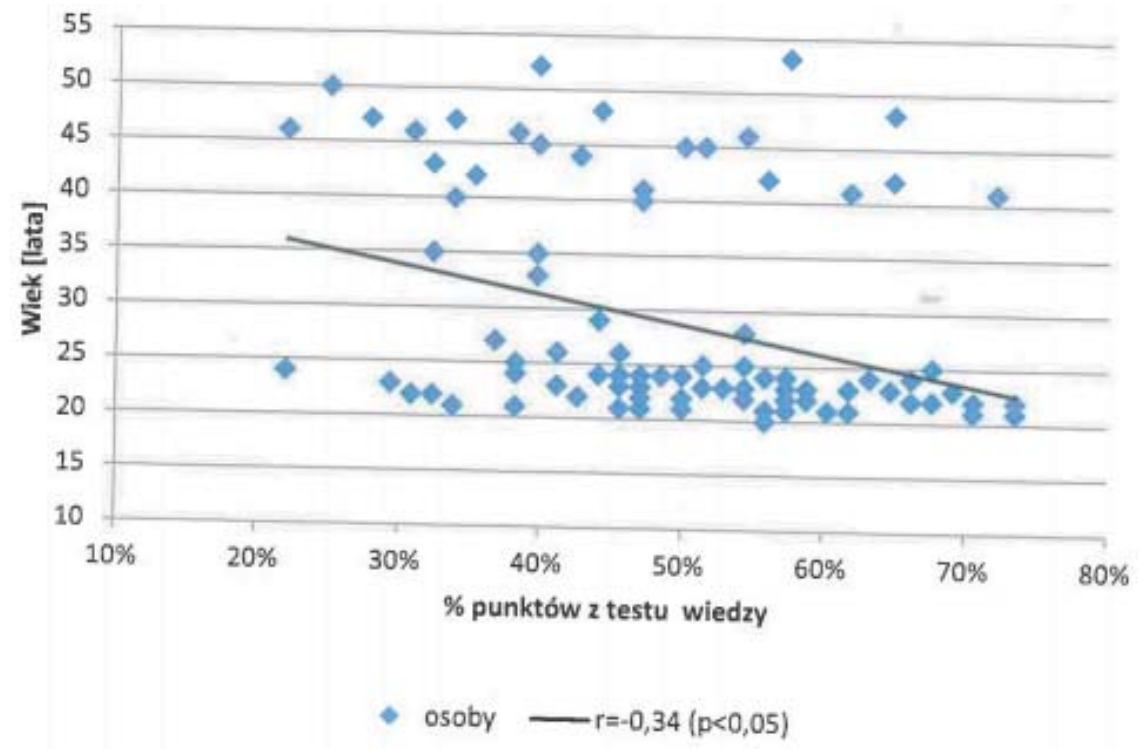

Rycina 2. Zależność prawidłowych odpowiedzi od wieku ankietowanych Figure 2. The relationship between correct answers and the age of the respondents

Źródło: badania własne

Source: author's own materials

\section{Dyskusja}

Badanie mikrobiologiczne krwi jest obecnie powszechnym narzędziem wykorzystywanym $w$ diagnostyce zakażeń o różnej lokalizacji. Wczesna i poprawna identyfikacja czynnika bakteriemii dostarcza istotnych informacji umożliwiających rozpoznanie i leczenie.
Pobieranie krwi do badań bakteriologicznych jest zadaniem personelu pielęgniarskiego. Prawidłowość wykonania zabiegu zależy od jego wiedzy oraz umiejętności.

Prawdopodobnie największym problemem globalnym jest pokoleniowa wymiana kadr i związane $z$ tym odpowiednie przygotowanie współpracowników i przy- 
szłych profesjonalistów. Gaines [4] stwierdził, że poziom wiedzy nie rósł wraz z poziomem edukacji oraz stażem pracy. W swej publikacji D’Alessandro i wsp. [5] wykazali, że studenci w wieku do 24 lat posiadali szerszą prawidłową wiedzę niż ich starsze koleżanki (maksymalny wiek 59 lat). To zjawisko tłumaczono szybszym i bardziej efektywnym procesem uczenia się u młodszych osób.

Jak sugerują Gawron-Skarbek i wsp. [6], słabą stroną procesu kształcenia przyszłej kadry medycznej jest częsty brak kontroli nad studentami w trakcie zajęć praktycznych: w zakresie, czy i w jaki sposób respektują oni podstawowe zasady higieny podczas kontaktu z pacjentem i materiałem zakaźnym. Jeśli już podczas procesu kształcenia studenci nie wyrobili w sobie poprawnych nawyków higienicznych, to w przyszłości będą powielać negatywne wzorce. Aż $60 \%$ badanych studentów uważało, że prowadzący zajęcia własnym przykładem nie w pełni motywowali studentów do przestrzegania zasad higieny, a co czwarty z badanych twierdził, że takiej motywacji ze strony prowadzących zajęcia nie dostrzegał wcale [6]. Wg Bringsvor i wsp. [7] w przypadku wątpliwości co do zrozumienia procedury pielęgniarki wykorzystają kontakty koleżeńskie i własne doświadczenie, a nie opracowania naukowe poparte dowodami (ang. evidence based resources). Profetto-McGrath i wsp. [8] stwierdzili, że pielęgniarki z tytułem magistra lub doktora częściej korzystały z medycznej literatury naukowej jako źródła wiedzy przy podejmowaniu decyzji, zwłaszcza jeśli literatura była dostępna w Internecie.

W wielu krajach wypowiadane są liczne uwagi krytyczne na temat poziomu edukacji pielęgniarek oraz ich gotowości do podjęcia pracy. Szczególnie widoczne są różnice, gdy porównuje się osoby, które niedawno ukończyły studia, z osobami z długim stażem zawodowym [9]. Pielęgniarka-nauczyciel odgrywa bardzo ważną rolę w procesie kształcenia studentów, zwłaszcza podczas stosowania wiedzy teoretycznej w codziennej pracy [5, 10].

Pozytywne wzorce zachowań obserwowane u przełożonych (lub innych pracowników postrzeganych jako stojących wyżej w hierarchii zawodowej) zwiększały przestrzeganie procedur przez pozostałych członków personelu. Jeżeli natomiast na sali znajdował się doświadczony pracownik, który nie przywiązywał wagi do prawidłowej higieny rąk, to początkujący pracownicy również nie przestrzegali odpowiednich zasad. Negatywne wzorce lansowane (świadomie czy nie) przez starszych pracowników były zdecydowanie częściej niż zachowania pozytywne powielane przez młodszych [11-13].

Wyniki badań przeprowadzonych przez Fell [14] dowiodły, że zajęcia praktyczne mogą pomóc zrozumieć rolę badań laboratoryjnych $w$ pracy pielęgniar- skiej. Al-Hamad i wsp. [15] przedstawili wyniki wpływu 30-minutowego przeznaczonego dla personelu pielęgniarskiego szkolenia, na którym wyjaśniano, jakie skutki ma „łamanie” procedur dla wyniku badania mikrobiologicznego. Mimo że w szkoleniu wzięło udział tylko $43 \%$ zatrudnionych w szpitalu pielęgniarek, zaowocowało ono spadkiem odsetka zanieczyszczonych próbek krwi z 9,95 do 3,5\% bezpośrednio po cyklu szkoleń. Niestety już po 2 miesiącach odsetek wzrósł do $5,7 \%$.

Bitsika i wsp. [16] porównali dwie metody uczenia studentów kaniulacji naczyń: metody z zastosowaniem komputerowego programu $z$ wirtualnymi symulatorami i tradycyjnej metody z zastosowaniem manekinów. Pierwsza metoda cieszyła się dużym zainteresowaniem wśród studentów, zwłaszcza nowicjuszy. Jednakże pod względem przygotowania studenta do praktycznego wykonania zabiegu u pacjenta bardziej skuteczna okazała się metoda z manekinem. Najlepsze wyniki uzyskano przy połączeniu e-learningu z konwencjonalnymi metodami nauczania. Autorzy podkreślili, iż ogromnym wyzwaniem w edukacji studentów pielęgniarstwa było nauczenie: rozpoznawania i raportowania przełożonym sytuacji niebezpiecznych (ang. hazards and near-misses), sposobów naprawienia popełnionych błędów oraz wyciągania wniosków z ww. sytuacji [16].

Do zjawisk/czynności, które naszym zdaniem wymagają szczegółowego omówienia, należy zaliczyć: ilość pobieranych próbek krwi, procedura dezynfekcji rąk oraz stosowanie środków ochrony indywidualnej.

W naszym badaniu tylko $13 \%$ ankietowanych wiedziało, iż pobranie tylko jednego posiewu krwi poza zmniejszeniem prawdopodobieństwa wyhodowania patogenu w większości przypadków uniemożliwia prawidłową interpretację wyniku - ustalenie, czy wyhodowano czynnik etiologiczny zakażenia, czy izolowany drobnoustrój jest zanieczyszczeniem. W dobie poszukiwania oszczędności z podobnymi problemami boryka się wiele ośrodków w świecie. Jak wynika z naszych obserwacji, ten błąd jest również jednym z najczęściej spotykanych w praktyce klinicznej (dane niepublikowane). Niższy odsetek pobierania pojedynczych próbek krwi oraz niższą częstość kontaminacji próbek zaobserwowano w szpitalach, w których tę procedurę wykonywał specjalnie przeszkolony personel, w porównaniu z ośrodkami, gdzie takie zasady nie obowiązywały $(2,6 \%$ vs $5,6 \%)[17,18]$. Pobieranie odpowiedniej liczby próbek i zmniejszenie liczby fałszywie dodatnich posiewów krwi bezpośrednio przełożyło się na obniżenie kosztów hospitalizacji (krótszy czas pobytu w szpitalu, krótszy czas antybiotykoterapii) [19].

Globalnym problemem medycznym pozostają nadal dezynfekcja rąk i adekwatne stosowanie środków 
ochrony indywidualnej wśród personelu medycznego. W naszym badaniu 35,8\% ankietowanych nie widziało potrzeby dezynfekcji rąk w procedurze pobierania krwi do badań mikrobiologicznych, a 40\% miało problemy z wiedzą na temat właściwej oceny czasu działania preparatu dezynfekcyjnego. W literaturze najczęściej podawanymi powodami braku dezynfekcji rąk przy procedurze pobierania krwi były brak czasu i brak dozownika antyseptyku w najbliższym otoczeniu pacjenta [20]. Poziom zgodności przestrzegania procedur higienicznej dezynfekcji rąk w Irlandii w 2002 roku wynosił 51\% [21]. Wyniki badań przeprowadzonych w szpitalach uniwersyteckich w Birmingham wskazały, że stosowanie rękawiczek ochronnych podczas pobierania krwi było bardzo ważne lub ważne dla 98,6\% pielęgniarek, ale tylko 79,7\% używało ich w praktyce [12]. Najczęstszymi zgłaszanymi przyczynami braku stosowania rękawiczek ochronnych były trudności w wyczuwaniu żył do iniekcji oraz obniżenie sprawności manualnej [12].

Z punktu widzenia mikrobiologa wiedza ankietowanych studentów pielęgniarstwa była niewystarczająca. Taki wynik może prowadzić do powstawania istotnych błędów przedanalitycznych. Uzyskane wyniki ankiety potwierdzają, że w trosce o hospitalizowanego pacjenta konieczne są systematyczne szkolenia personelu pielęgniarskiego przez personel laboratorium mikrobiologicznego. Zasadniczą funkcję w pogłębianiu umiejętności powinny pełnić uczelnie kształcące personel medyczny - adeptki powinny odbywać uzupełniające się zajęcia teoretyczne i praktyczne. Drugim ważnym elementem w procesie kształcenia pielęgniarek powinny być procedury mikrobiologiczne [3] zawsze dostępne w każdym oddziale, tak dla personelu, jak i osób uczących się (studentów, stażystów i praktykantów). Szczególnie w naszej uczelni dbamy o to, aby procedury te były spójne z aktualną wiedzą medyczną i wiadomościami przekazywanymi na zajęciach.

W procesie nauczania i szkolenia należy zwrócić baczniejszą uwagę pielęgniarek na rolę badań bakteriologicznych w rozpoznawaniu zakażeń. Przez dostatecznie opanowaną technikę manualną należy rozumieć również: prawidłowe wypełnienie skierowania, umiejętność doboru podłoża transportowego i innych wyrobów medycznych, prawidłowe oznaczenie materiału, zachowanie warunków przechowywania i transportu - tak aby uniknąć wpływu błędów przedanalitycznych na wynik badania mikrobiologicznego posiewu krwi. W naszej opinii częstość pobierania krwi wśród uczących się jest niewystarczająca do uzyskania i utrzymania umiejętności na odpowiednim poziomie, dlatego w procesie szkolenia konieczne jest zwiększenie ilości zajęć praktycznych. Zwracamy również uwagę na ogromne zagrożenie wynikające z gorszego przygoto- wania starszej kadry pielęgniarek, które w oddziałach mogą pełnić funkcję lokalnego autorytetu i stanowić źródło wiedzy praktycznej dla młodszego personelu. Właśnie grupa starszych pielęgniarek jest tą grupą, na którą podczas szkoleń okresowych należy zwrócić szczególną uwagę. Ponadto lekarz zlecający posiew krwi powinien mieć pełną świadomość ograniczeń wynikających z wiedzy i doświadczenia personelu, który będzie pobierał materiał do badania mikrobiologicznego, i że fakt ten może w dużej mierze wpływać na jakość uzyskanego wyniku.

\section{Wnioski}

1. Z punktu widzenia mikrobiologa wiedza ankietowanej grupy była niewystarczająca, taki poziom wiedzy może prowadzić do powstawania istotnych błędów przedanalitycznych w pracy przy pacjencie.

2. W trakcie pracy zawodowej wiedza na temat pobierania materiału ulega z czasem osłabieniu, a nawet zanikowi.

3. Zasadniczą rolę w pogłębianiu umiejętności powinny odgrywać uczelnie kształcące personel medyczny, w miejscu pracy natomiast konieczne jest prowadzenie regularnych szkoleń z zakresu pobierania materiału do badań mikrobiologicznych; należy przy tym zwrócić szczególną uwagę, by szkolenia te objęły również starszą kadrę.

\section{Piśmiennictwo}

1. Ustawa z dnia 15 lipca 2011 r. o zawodach pielęgniarki i położnej. Dz.U. 2014 poz. 1435.

2. Rozporządzenie Ministra Zdrowia z dnia 7 listopada 2007 r. w sprawie rodzaju i zakresu świadczeń zapobiegawczych, diagnostycznych, leczniczych i rehabilitacyjnych udzielanych przez pielęgniarkę lub położną samodzielnie bez zlecenia lekarskiego. Dz.U. 2007 Nr 210, poz. 1540.

3. Rozporządzenie Ministra Zdrowia z dnia 21 stycznia 2009 r. zmieniające rozporządzenie w sprawie standardów jakości dla medycznych laboratoriów diagnostycznych i mikrobiologicznych. Dz.U. 2009 Nr 22, poz. 128.

4. Gaines C. Needed: A knowledge translation skill set. Nurse Educ Today. 2014; 34: 487.

5. D'Alessandro D, Agodi A, Auxilia F, Brusaferro $S$ et al. Prevention of healthcare associated infections: Medical and nursing students' knowledge in Italy. Nurse Educ Today. 2014; 34: 191-195.

6. Gawron-Skarbek A, Nowacka E, Łaszek M, Szatko F. Negatywne wzorce zachowań studentów. Część III. Respektowanie norm higienicznych w kontakcie z materiałem zakaźnym. Probl Hig Epidemiol. 2011; 92: 466-473.

7. Bringsvor HB, Bentsen SB, Berland A. Sources of knowledge used by intensive care nurses in Norway: An exploratory study. Intens Crit Care Nurs. 2014; 30: 159-166.

8. Profetto-McGrath J, Bulmer Smith K, Hugo K, Taylor M, El-Hajj H. Clinical Nurse Specialists' Use of Evidence in Practice: A Pilot Study. Worldviews Evid Based Nurs. 2007; 4: 486-496. 
9. Pijl-Zieber EM, Barton S, Konkin J, Awosoga O, Caine V. Mind the gap: Quantifying the performance gap between observed and required clinical competencies in undergraduate nursing students. Nurse Educ Today. 2014; 34: 667-669.

10. Erasmus V, Brouwer W, van Beeck EF et al. A qualitative exploration of reasons for poor hand hygiene among hospital workers: lack of positive role models and of convincing evidence that hand hygiene prevents cross-infection. Inf Control Hosp Epid. 2009; 30: 415-419.

11. Cole M. Exploring the hand hygiene competence of student nurses: A case of $\mathrm{fl}$ awed self assessment. Nurse Educ Today. 2009; 9: 380-388.

12. Garus A, Szatko F. Przestrzeganie wzorców zachowań higienicznych przez personel medyczny w szpitalach. Probl Hig Epidemiol. 2006; 87: 176-181.

13. Joshi SC, Diwan V, Tamhankar A et al. Qualitative study on perceptions of hand hygiene among hospital staff in a rural teaching hospital in India. J Hosp Inf. 2012; 80: 340-344.

14. Fell P. Can laboratory practical-based learning enhance nurse graduates bioscience knowledge and key skills required for the workplace? (Dostępne w Internecie:) http:// www.heacademy.ac.uk/resources/detail/teaching-development-grants/individual-round-1/enhance-nurse-graduates (data dostępu: 27.12.2016).

15. Al-Hamad A, Al-Ibrahim M, Alhajhouj E, Jaffer WA, Altowaileb J, Alfaraj $\mathrm{H}$. Nurses' competency in drawing Blood cultures and education intervention to reduce the contamination rate. J Infect Public Heath, http://dx.doi.org/10.1016/j. jiph.2015.06.007 (data dostępu: 27.12.2016).

16. Bitsika $\mathrm{E}$, Karlis $\mathrm{G}$, lacovidou $\mathrm{N}$ et al. Comparative analysis of two venipuncture learning methods on nursing students. Nurse Educ Today. 2014; 34: 15-18.

17. Stefaniuk E. Postępowanie w diagnostyce bakteryjnych zakażeń dolnych dróg oddechowych. Post Mikrobiol. 2006; 45: $67-76$.
18. Weinstein MP. Contaminated or not? Guidelines for interpretation of positive blood cultures. Web M\&M morbidity \& mortality rounds on the web 2008, http://webmm.ahrq.gov/printviewCase.aspx?caselD=168 (data dostępu: 27.12.2016).

19. Snyder SR, Favoretto AM, Baetz RA et al. Effectiveness of practices to reduce blood culture contamination: a Laboratory Medicine Best Practices systematic review and metaanalysis. Clin Biochem. 2012; 45: 999-1011.

20. Hall KK, Lyman JA. Updates review of blood culture contamination. Clin Microbiol Rev. 2006; 19: 788-797.

21. Creedon S. Healthcare workers' hand decontamination practices: compliance with recommended guidelines. J Adv Nurs. 2005; 51: 208-16.

Artykuł przyjęty do redakcji: 30.12.2016

Artykuł przyjęty do publikacji: 13.02.2017

Źródło finansowania: Praca nie jest finansowana z żadnego źródła. Konflikt interesów: Autorzy deklarują brak konfliktu interesów.

Adres do korespondencji:

Beata Sokół-Leszczyńska

ul. Tytusa Chałubińskiego 5

02-004 Warszawa

tel.: 226282739

e-mail: beata.sokol-leszczyska@wum.edu.pl

Katedra i Zakład Mikrobiologii Lekarskiej

Warszawski Uniwersytet Medyczny

Część wyników pracy prezentowana była podczas konferencji Interdyscyplinarny wymiar zdrowia i choroby zorganizowanej przez WUM 27-28 listopada 2014 roku oraz podczas XXVIII Zjazdu Polskiego Towarzystwa Mikrobiologów Mikrobiologia - nowe wyzwania, nowe możliwości, Bydgoszcz, 25-27 września 2016 roku. 